\title{
RELATIONSHIP OF REFRACTION CLAIMS WITH STUDENT ACHIEVEMENT IN SMP NEGERI PADANG CITY
}

\author{
FEBRY CORINA, PENI OKTO RANDI, RINA NOVALINDA
}

Akademi Refraksi Optisi YLPTK Padang

\begin{abstract}
Abstrak: Masalah penglihatan yang berkaitan dengan proses belajar meliputi defisit efisiensi dan pemrosesan informasi visual yang berpotensi mengganggu kemampuan belajar seseorang. Tujuan dari penelitian ini adalah untuk mengetahui hubungan antara kelainan refraksi dengan prestasi belajar siswa. Jenis penelitian ini adalah deskriptif kuantitatif. Populasi dalam penelitian ini adalah 30 remaja di SMP Negeri Kota Padang. Pembahasan diurutkan sesuai dengan rumusan masalah. Berdasarkan hasil penelitian diketahui bahwa 33,3\% mahasiswa mengalami kelainan refraksi miopia. Selain itu, terdapat hubungan yang signifikan antara kelainan refraksi dengan prestasi belajar siswa di SMP Negeri Kota Padang. Siswa yang merasa penglihatannya kabur untuk melihat jauh harus segera memeriksakan matanya dan juga harus berhati-hati dengan ciri-ciri kelainan miopia dan kelainan refraksi lainnya. Disarankan agar siswa yang memiliki kebiasaan membaca yang salah lebih memperhatikan kesehatan mata agar tidak terjadi hal-hal yang tidak diinginkan.
\end{abstract}

Kata kunci: Remaja, Miopia refraksi. Prestasi belajar

\begin{abstract}
Vision problems related to the learning process include deficits in efficiency and processing of visual information that have the potential to interfere with a person's ability to learn. The purpose of this study was to determine the relationship between refractive errors and student achievement. This type of research is descriptive quantitative. The population in this study was 30 adolescents at SMP Negeri Padang City. The discussion is sorted according to the formulation of the problem. Based on the results of the study, it was found that $33.3 \%$ of the students had refractive errors myopia. In addition, there is a significant relationship between refractive errors and student achievement at SMP Negeri Padang City. Students who feel that their vision is blurry to see far away should immediately check their eyes and also have to be careful about the characteristics of myopia disorders and other refractive errors. It is recommended that students who have wrong reading habits pay more attention to their eye health so that unwanted things do not occur.
\end{abstract}

Keywords: Adolescence, Refractive myopia. Learning achievement

\section{A. Introduction}

Vision is one of the most important factors in all aspects of life, including the educational process. Vision is also the main line of information, therefore delays in making corrections, especially at school-age children, will greatly affect the ability to absorb learning material and reduce the potential for increasing intelligence (MOH, 2009). Even though its function for human life is very important, eye health is often neglected, so that many diseases that attack the eye are not treated properly and cause visual disturbances (refractive errors) to blindness. Refraction disorder is a disorder of refraction of light in the eye so that the light is not focused on the retina or yellow spots, but can be in front or behind the yellow spots and may not be located in a single focal point (Ilyas, 2004). Refractive disorders are usually caused by the habit of reading too closely, causing eye fatigue (astenopia) and excessive light radiation received by the eye, including computer and television light radiation (Gondhowiharjo, 2009). In computer-induced interference, this will lead to Computer Vision Syndrome (CVS)This situation causes the muscles that make up the accommodation in the eye to all work.

Uncorrected refractive errors are a major cause of low vision in the world and can lead to blindness. Data from VISION 2020, a collaborative program between the International Agency for the Prevention of Blindness (IAPB) and WHO, states that in 2006 an estimated 153 million people in the world experience visual disturbances due to uncorrected refractive 
errors. Of these 153 million people, at least 13 million of them are children aged 5-15 years, where the highest prevalence occurs in Southeast Asia (WHO, 2004). Refraction disorder is a term used to describe the inability of the retina to focus on an object properly. Refractive disorders occur when light entering the eye is not directly focused on the retina. Based on the Global Data on Visual Impairment in 2010, uncorrected refractive errors are the most common cause of visual disturbances in the world, namely $43 \%$, followed by cataracts in the second rank of $33 \%$, and glaucoma in the third rank of $2 \%$. Refractive disorders cause blindness in as much as $3 \%$ worldwide.

According to the Ministry of Health of the Republic of Indonesia in 2012, visual impairment and blindness are also health problems faced by society, with cataracts being the most common cause of visual disturbances and blindness (50\%). Another cause is refractive error (22.1\% of the total population) and as many as $15 \%$ are suffered by school age children. Some types of refractive errors are myopia, hypermetropia, presbyopia, and astigmatism. Myopia is a refractive disorder in which the eye is unable to refract light precisely in one focus to see objects clearly, where near objects are clearly visible but distant objects appear blurry. Myopia occurs when the eyeball is too long, so when the rays come from an infinite distance, the image will fall in front of the retina. Myopia can also occur because the cornea or lens is too curved due to the length of the eyeball.

Myopia is a refractive disorder that has a high incidence. In 2010, WHO estimates that $27 \%$ of the world's population has myopia and $2.8 \%$ of the world's population has high myopia. East Asia occupies the highest prevalence of myopia in the world, namely China, Japan, Korea, and Singapore, with a prevalence of around 50\%, and 69\% occurs in children aged 15 years who are included in school age. The lowest prevalence of myopia in the world is Australia, Europe, North and South America. This figure is expected to continue to increase to $33 \%$ in 2020 and $52 \%$ in 2050.

Hypermetropia or 414eridian414dness is a refractive disorder when a beam of light traveling parallel to the eye in a resting state without accommodation is refracted to form an image behind the retina. The optical power of the eye is too low, usually due to the shortness of the eyeball, causing parallel rays of light to converge at a point behind the retina. Hypermetropia often occurs in adulthood and is directly proportional to age. There are several things that cause hypermetropia, namely: 1) The axial axis of the eyeball is shorter than normal (axial hypermetropy), which causes the shadow to fall in front of the retina. A difference in the length of the eyeball of $1 \mathrm{~mm}$ causes a difference of 3 diopters, usually not more than $2 \mathrm{~mm}$ if more than that there is another pathological condition. 2) The radius of the curvature of the cornea and lens is smaller than normal (hypermetropia curvature). 3) Change the position of the lens that is farther back. Often occurs in trauma or post-cataract surgery aphakia. 4) Changes in the refractive index of refraction, often in old age where there is a change in the consistency and opacity of the cortex and nucleus of the lens which causes the refractive index to increase.

Astigmatism is the habituation of more than one focal point of the parallel beam entering the eye in a state without accommodation. Astigmatism is classified based on shape and type, based on the form divided into regular and irregular astigmatism. In regular astigmatism there are main meridians that are perpendicular to each other, each of which has the strongest and weakest refractive power, whereas in irregular astigmatism, irregular focal points are obtained. The division based on the type is divided into 5, namely: 1) Hypermetropia simplex astigmatism, one of the main meridians of emetropia and the other main 414eridian hypermetropia; 2) Simple myopia astigmatism, one of the main meridians of emetropia and myopia and the other major myopia; 3) Compositus hypermetropia astigmatism, the two major meridians of hypermetropia to different degrees; 4) Compisitus myopia astigmatism, the two main meridians of myopia with different degrees and 5) Myopia astigmatism, one hypermetropic prime meridian and the other myopia main meridian. 
Furthermore, in 2010 data, as much as $43 \%$ of the causes of visual disturbances were uncorrected refractive errors (WHO, 2012). Refractive disorders are considered common in children, nearly 13.5 million children aged 0 to 17 years are affected by visual disturbances (Ferebee, 2004). Four percent of the causes of blindness in the world are caused by visual disturbances that have not been corrected since childhood (WHO, 2012). In Indonesia, according to basic health research (riskesdas) in 2013, the prevalence of blindness in Indonesia is still considered quite high, namely $0.6 \%$ of the total population, considered high if it exceeds $0.5 \%$. The national prevalence of severe low vision for people aged 6 years and over is $0.9 \%$. Refractive disorders are one of the causes of blindness that can be easily detected, treated and evaluated with glasses, however, refractive errors become a serious problem if they are not treated quickly. About 10\% of school-age children (5-19 years) suffer from refractive errors and the number of wearing corrected glasses is still low, namely $12.5 \%$ of the need (Ilyas, 2006).

Considerable evidence regarding the association of learning disabilities due to visual impairment and achievement, from theory as well as empirical evidence, finds a causal relationship. Specifically linked abilities are tracking (for example the ability to read a sentence while reading), teaming or binocularity (for example communication between the eye and the brain), and focusing (for example the ability to concentrate accurately over a wide range of distances, change concentration rapidly, and maintain concentration. As long as it takes). Symptoms of performance-threatening visual impairment include frequent eye rubbing and blinking, short concentration of concentration, avoidance of reading or close activities, frequent dizziness, closing one eye, tilting the head to one sid.

Vision problems related to the learning process include deficits in efficiency and processing of visual information that have the potential to interfere with a person's ability to learn. This deficit can manifest as blurred vision, headaches and difficulty reading. Eye acuity screening in elementary school children is one of the activities carried out to identify children's eye disorders. Children with refractive errors will get a referral to use glasses so that they do not get worse. Research in Brazil in 2010 stated that visual disturbances that occur at an early age will interfere with the development of motor skills, knowledge and language during the child's development period.7 In Indonesia, the results of research on students of SMP Kristen Eben Haezar 2 Manado class VIII in 2014 indicated that the refraction was significantly associated with learning achievement. However, research on outstanding students at SD Panca Budi Medan in 2014 did not find a significant relationship between refractive errors and achievement levels.

Considering that there are still contradictions from several studies that have been conducted and the absence of similar research in the Bungo Village area of Jambi Province, further research is necessary. Based on the above background, the researcher is interested in knowing the effect of refractive errors on student achievement at SMP Negeri Padang City

\section{B. Method Research}

The type of research used is descriptive quantitative, the research process is carried out through interviews by distributing questionnaires. The population in this study were all students who experienced myopia refractive error. The sample in this study were all children who had myopia refractive error, amounting to 30 people. The research was conducted at SMP Negeri Padang City.

\section{Results and Discussions \\ 1. Research result}

The research data were taken from filling out a questionnaire of 30 students and the examination was carried out after filling in the questionnaire who had complaints about myopia disorders in students at SMP Negeri Padang City, the following results were obtained: 
a) Myopia Refraction Disorders at SMP Negeri Padang City

Table 1 Frequency Distribution of Student Myopia Refraction

Abnormalities at SMP Negeri Padang City

\begin{tabular}{|c|l|c|c|}
\hline No & \multicolumn{1}{|c|}{ Indicator } & Yes & \% \\
\hline 1 & Using glasses & 4 & 13.33 \\
\hline 2 & Blurred vision when looking far & 11 & 36.66 \\
\hline 3 & Often squints when he sees writing on print media or HP & 10 & 33.33 \\
\hline 4 & Often rubbing eyes after playing with cellphones or reading books & 11 & 36.67 \\
\hline 5 & Often rubbing his eyes when reading the small writing on the blackboard & 13 & 43.33 \\
\hline 6 & Often feel the headache throbbing, especially in the front & 17 & 56.67 \\
\hline 7 & The eyes get tired easily while reading & 15 & 50 \\
\hline 8 & Seeing multiple objects with one or both eyes & 7 & 23.33 \\
\hline 9 & See more clearly when an object is brought closer in front of the eye & 7 & 23.33 \\
\hline 10 & See an object / object that is round to be oval & 5 & 16.67 \\
\hline & Total & $\mathbf{1 0 0}$ & $\mathbf{3 3 . 3}$ \\
\hline
\end{tabular}

Based on table 1, it can be seen from 30 students that all the students who were sampled, only $13.33 \%$ used glasses, $36.67 \%$ had blurred vision when looking far away, $33.33 \%$ of students often squinted when they saw writing in printed media or Cell phones, $36.67 \%$ often rubbed their eyes after playing with their cellphones or reading books, $43.33 \%$ of students rubbed their eyes frequently when reading small writing on the blackboard, $56.67 \%$ of students often felt head pain throbbing, especially on the front, 50\% of students felt the eyes get tired easily when reading, $23.33 \%$ of students mlook at multiple objects with one or both eyes, $23.33 \%$ of students will msee more clearly when an object is brought closer in front of the eye, and $16.67 \%$ of studentssee an object / object that is round to become oval.

b) Student achievement at SMP Negeri Padang City

Table 2 Frequency Distribution of Student Achievement at SMP Negeri Padang City

\begin{tabular}{|c|c|c|c|c|c|c|c|c|c|c|}
\hline $\begin{array}{c}\text { Serial } \\
\text { number }\end{array}$ & \multicolumn{10}{|c|}{ Learning Achievement (UH Score) } \\
\hline Absent & MTK & IPA & IPS & BHS & ENG & PKN & ART & ORG & PIE & $\begin{array}{c}\text { Avera } \\
\text { ge }\end{array}$ \\
\hline 1 & 87 & 80 & 87 & 87 & 87 & 80 & 87 & 87 & 87 & 85.44 \\
\hline 2 & 88 & 82 & 88 & 60 & 61 & 62 & 60 & 88 & 88 & 75.22 \\
\hline 3 & 80 & 83 & 80 & 80 & 89 & 80 & 80 & 80 & 80 & 81.33 \\
\hline 4 & 76 & 76 & 76 & 76 & 87 & 81 & 76 & 76 & 76 & 77.78 \\
\hline 5 & 78 & 78 & 78 & 78 & 85 & 80 & 78 & 78 & 78 & 79.00 \\
\hline 6 & 88 & 88 & 88 & 88 & 76 & 66 & 76 & 76 & 88 & 81.56 \\
\hline 7 & 89 & 89 & 89 & 70 & 85 & 65 & 89 & 89 & 89 & 83.78 \\
\hline 8 & 86 & 83 & 86 & 70 & 76 & 64 & 76 & 86 & 86 & 79.22 \\
\hline 9 & 85 & 82 & 85 & 70 & 81 & 81 & 85 & 85 & 85 & 82.11 \\
\hline 10 & 89 & 76 & 76 & 76 & 76 & 76 & 76 & 89 & 89 & 80.33 \\
\hline 11 & 87 & 82 & 87 & 76 & 89 & 89 & 87 & 87 & 87 & 85.67 \\
\hline 12 & 85 & 78 & 85 & 76 & 87 & 84 & 89 & 82 & 85 & 83.44 \\
\hline 13 & 86 & 88 & 70 & 75 & 60 & 61 & 62 & 60 & 86 & 72.00 \\
\hline 14 & 85 & 67 & 70 & 75 & 76 & 76 & 76 & 76 & 85 & 76.22 \\
\hline 15 & 84 & 78 & 70 & 75 & 81 & 84 & 86 & 80 & 84 & 80.22 \\
\hline 16 & 81 & 72 & 76 & 75 & 85 & 81 & 85 & 80 & 81 & 79.56 \\
\hline
\end{tabular}




\begin{tabular}{|l|l|l|l|l|l|l|l|l|l|l|}
\hline 17 & 67 & 70 & 70 & 67 & 70 & 60 & 65 & 66 & 60 & 66.11 \\
\hline 18 & 89 & 85 & 76 & 76 & 76 & 76 & 76 & 81 & 89 & 80.44 \\
\hline 19 & 87 & 86 & 75 & 84 & 85 & 87 & 85 & 85 & 87 & 84.56 \\
\hline 20 & 85 & 85 & 75 & 85 & 85 & 85 & 89 & 89 & 85 & 84.78 \\
\hline 21 & 86 & 86 & 75 & 60 & 61 & 62 & 60 & 84 & 86 & 73.33 \\
\hline 22 & 85 & 85 & 75 & 85 & 85 & 78 & 85 & 77 & 85 & 82.22 \\
\hline 23 & 84 & 84 & 80 & 84 & 84 & 88 & 86 & 80 & 84 & 83.78 \\
\hline 24 & 81 & 81 & 80 & 76 & 76 & 76 & 76 & 80 & 81 & 78.56 \\
\hline 25 & 65 & 83 & 89 & 89 & 89 & 86 & 84 & 84 & 89 & 84.22 \\
\hline 26 & 60 & 60 & 61 & 62 & 60 & 63 & 67 & 65 & 63 & 62.33 \\
\hline 27 & 69 & 70 & 85 & 85 & 85 & 87 & 85 & 85 & 85 & 81.78 \\
\hline 28 & 86 & 68 & 86 & 86 & 86 & 85 & 89 & 89 & 86 & 84.56 \\
\hline 29 & 79 & 67 & 79 & 70 & 80 & 86 & 87 & 84 & 80 & 79.11 \\
\hline 30 & 79 & 60 & 75 & 70 & 80 & 80 & 80 & 76 & 77 & 75.22 \\
\hline
\end{tabular}

Based on table 2, it can be seen that the average student achievement in all subjects is in the good category, it's just that there are some students who are under the KKM as in serial numbers 17 and 26.

c) Relationship between myopia refraction and student achievement disorders at SMP Negeri Padang City

Table 3 The Relationship between Student Achievement and

Myopia Refraction Disorders at SMP Negeri Padang City

Correlations

\begin{tabular}{|l|l|r|r|}
\hline & \multicolumn{1}{|c|}{ LM } & \multicolumn{2}{|c|}{ KM } \\
\hline \multirow{2}{*}{$\begin{array}{l}\text { Learning } \\
\text { achievement }\end{array}$} & Pearson & 1 & $0.613 * *$ \\
& Correlation & & 0.000 \\
& Sig. (2-tailed) & 30 & 30 \\
N & Pearson & $0.613 * *$ & 1 \\
Myopia & Correlation & 0.000 & 30 \\
Refractive & Sig. (2-tailed) & 30 & \\
Disorders & $\mathrm{N}$ & & \\
& & & \\
\end{tabular}

**. Correlation is significant at the 0.01 level (2-tailed).

From the results of the correlation analysis using SSS version 20.00, the correlation coefficient is 0.613 ( $\mathrm{r}$ count) while $\mathrm{r}$ table $=0.323$ at the $5 \%$ significance level, meaning that $r$ count> $r$ table. So it can be concluded that there is a significant relationship between refractive errors myopia and student achievement at SMP Negeri Padang City. If students experience myopia refractive error, their learning achievement tends to decline.

\section{Discussion}

Research from the American Academy of Ophthalmology says that children's visual experiences play an important role in psychological, physical and intellectual development. Impaired vision due to refractive errors is a significant cause of morbidity in children worldwide.

Based on research Hartanto et al (2010) found myopia refractive error with the most presentation. Research by Saw (2003) in Sumatra, Wu in America and Bastanta (2010) also found that most refractive errors are myopia. Research by Handayani et al (2011) found that myopia had the highest frequency in the 11-20 year age group (25.1\%). This happens maybe because this age group is a group of school children, higher activity and the influence of E-ISSN: 2657-0300 Lembaga Penelitian dan Penerbitan Hasil Penelitian Ensiklopedia 
computer use. In line with previous research, in this study it was found that class VIII students of SMP Kr. Eben Haezar 2 Manado was most diagnosed with myopia refractive error (32\%).

The Ministry of National Education (2006) categorizes several levels regarding student mastery, among others, $(1) \geq 80-100$ with very good criteria which means mastering almost all concepts, (2) $\geq 70-<80$ with good criteria which means mastering most concepts, (3) $\geq 60$ - $<70$ with sufficient criteria which means mastering half of the concepts, (4) $\geq 50$ - $<60$ with insufficient criteria which means mastering a small number of concepts, (5) $<50$ with very poor criteria which means almost not mastering concept. In this study, the average scores for the most recent learning outcomes achieved were 70-80 (50\%) and 80-90 (48\%).

Research Lian Hong (2010) reported that children in academic schools spend more time reading and writing than regular schools. In grades $1-3$, the difference in learning time can be up to 107 minutes per day, and in grades 4-6 and grades 7-9, the difference in learning time can be up to 160 and 224 minutes per day. The results reflect a close relationship between learning intensity and myopia. Similar results were obtained from studies in Singapore (2002), Israel (1993), rural areas in North China (2001), Hong Kong (1993) and Orinda (2002). In this study, in line with previous studies, it was found that most respondents suffered from myopia refractive error with an average value of the latest learning outcomes achieved was 70-80.

\section{Conclusions}

Based on the results of research on the relationship between learning achievement and refractive error myopia students at SMP Negeri Padang City, the following conclusions are obtained: 1) Of the 30 students who experienced myopia refractive error. 2) There is a significant relationship between myopia refractive error and student achievement at SMP Negeri Padang City. Acknowledgments. The author expresses his gratitude to various parties who have deigned to take the time and contribute ideas until the completion of this research proposal properly. Hopefully all kindness and help will all get blessings from Allah SWT. In conclusion, the authors hope that this research proposal can be useful for all parties who need it.

\section{References}

American Association of Pediatric Ophthalmology and Strabismus, American Academy of Ophthalmology. 2003. Policy statement: Eye examination in infants, children and young adults by pediatricians. Pediatrics; 111:902-07.

American Academy of Ophthalmology. 2011. Refractive Surgery. San Fransisco: Basic and Clinical Science Course.

Hartanto W, Inakawati S. (2010). Kelainan Refraksi Tak Terkoreksi Penuh di RSUP Dr. Kariadi Semarang periode 1 Januari 2002-31 Desember 2003. Media Medika Muda. 4: 26-7.

Ilyas Sidarta. .2005. Ilmu penyakit mata. Jakarta: Fakultas Kedokteran Universitas Indonesia. 2008. Ilmu penyakit mata. Jakarta: Fakultas Kedokteran Universitas Indonesia.

Lian-Hong Pi, Lin Chen, Qin Liu, Ning Ke, Jing Fang, Shu Zhang, Jun Xiao, Wei-Jiang Ye, Yan Xiong, Hui Shi, Zheng-Qin Yin. 2010. Refractive Status and Prevalence of Refractive Errors in Suburban School-age Children. Int J Med Sci. 7(6): 342-353. 